\title{
A SISTEMÁTICA DAS TUTELAS PROVISÓRIAS NO NOVO CÓDIGO DE PROCESSO CIVIL E A SUA INFLUÊNCIA NO DIREITO MARCÁRIO BRASILEIRO
}

\author{
José Carlos Vaz e Dias ${ }^{1}$ \\ Fabiana Marcello Gonçalves Mariotini ${ }^{2}$
}

\section{Resumo}

O texto elenca as principais alterações promovidas pelo Novo Código de Processo Civil brasileiro (NCPC) no que diz respeito à sistemática das tutelas provisórias, destacando a importância de tais mudanças no âmbito do direito da propriedade industrial, mais especificamente no direito marcário. O cerne do presente estudo é analisar como o ideal de efetividade trazido no bojo do novel diploma é capaz de afetar a tutela de direitos historicamente negligenciados, como é o caso do direito das marcas.

Palavras-chave: Novo Código de Processo Civil, tutelas provisórias, direito marcário, direito da propriedade industrial, efetividade.

\section{CONSIDERAÇÕES INICIAIS: A TUTELA PROVISÓRIA NO PROCESSO CIVIL BRASILEIRO E A SUA IMPORTÂNCIA NO ÂMBITO MARCÁRIO}

Um dos temas mais intrigantes e fascinantes do direito processual civil brasileiro moderno diz respeito à sistemática das tutelas provisórias, notadamente à importância fulcral que estas exercem na busca da tão sonhada pacificação social, objetivo máximo da ciência processual.

Não é de hoje que a doutrina vem dispensando enorme atenção e cuidado no estudo desse instituto, o qual, sem dúvidas, sofreu consideráveis alterações pelo Novo Código de Processo Civil brasileiro (NCPC). As aludidas alterações se prestaram a dotar as tutelas provisórias de um maior grau de eficácia, aumentando a sua aplicabilidade prática.

As tutelas provisórias e as inovações trazidas pelo NCPC constituem objeto do presente trabalho, em especial a forma como a modificação na ordenação de tais tutelas potencializa a efetividade da proteção dos direitos da propriedade industrial (particularmente os sinais distintivos registráveis como marca).

Tais inovações trazidas pelo legislador permitem que, em tempo razoável, possa se garantir a proteção do

\footnotetext{
${ }^{1}$ Doutor em Direito pela Universidade de Kent - Inglaterra. Professor Adjunto da Universidade do Estado do Rio de Janeiro UERJ.E-mail: jose.dias@vdav.com.br

${ }^{2}$ Mestre em direito público pela Universidade Estácio de Sá - UNESA. E-mail: fmg@gcnlaw.com.br
} 
renome de uma marca, bem como a manutenção do fundo de comércio decorrente de investimentos ocorridos para fins de promoção deste bem jurídico intangível.

Saliente-se, preliminarmente, que, quando se opta por estudar matéria tão nova e polêmica, envolvendo significantes alterações implementadas pelo NCPC ao regramento anteriormente disposto pelo Código de Processo Civil de $1973(\mathrm{CPC} / 1973)^{3}$, torna-se imprescindível utilizar como premissa a seguinte assertiva: "não existem fórmulas de validade universal para resolver por inteiro as equações, devendo ser combinadas estratégias e táticas diversas" ${ }^{24}$.

Em vista disso, há que se ter em mente que, todo e qualquer estudo que se propõe a analisar o NCPC, representa apenas um ponto de partida para uma análise acurada das inovações que poderão demorar décadas para se consolidar, em vista da necessidade de acomodação das regras à realidade social e econômica do Brasil.

Não chegaremos, possivelmente, nos próximos anos, a axiomas e conclusões universalmente válidas. O que teremos serão mais perguntas do que respostas; mais dúvidas do que certezas; muito a se falar e pouco a se assegurar.

Esse ensaio tem como conviç̧ão relevante o fato de que não existem soluções prontas capazes de responder com satisfação às incertezas trazidas no bojo do diploma processual recém-vigente.

Nessa perspectiva, os autores do presente trabalho explicitam divagações jurídicas decorrentes de inquietações que sobressaltam sobre a nova matéria, face às peculiaridades dos direitos da propriedade industrial.

O regramento no NCPC pretende resgatar a imprescindibilidade das tutelas provisórias para os jurisdicionados (e para a própria higidez do sistema processual), as quais exercem papel fulcral na árdua tarefa de repartir equanimemente o ônus do tempo no processo, a fim de que se torne viável ao titular de um bem da vida alcançar (ou pelo menos se aproximar) da almejada "Justiça".

A nomenclatura utilizada pelo NCPC - tutela provisória - é capaz de indicar o grau de modificação do instituto, na medida em que o legislador, de maneira inédita, criou esse grande gênero que passa a englobar as tutelas de urgência (antigas conhecidas do Código de 1973) e as chamadas tutelas de evidência ${ }^{5}$, sendo certo que a inserção desta última espécie representa a principal alteração do instituto.

A grande modificação da ordenação até então vigente pode ser atribuída ao fato de que a alusão à

\footnotetext{
3 Lei n. 5.869, de 11 de janeiro de 1973 (revogada pela Lei 13.105, de 16 de março de 2015). Disponível: http://www.planalto.gov.br/ccivil_03/LEIS/L5869.htm. Acesso em 10 de dezembro de 2016.

${ }^{4}$ MOREIRA, José Carlos Barbosa. O futuro da justiça: alguns mitos. In: Temas de Direito Processual. Oitava Série. Rio de Janeiro: Editora Saraiva, 2004, p. 07.

${ }^{2}$ HARTMANN, Rodolfo Kronemberg. Novo Código de Processo Civil. 2a Ed. Rio de Janeiro: Impetus, 2016, p. 263. "Instituto inédito é o da 'tutela provisória' que, em certos momentos, justifica o desaparecimento do processo cautelar autônomo. Nesta hipótese, o que o pretende obter não é uma 'tutela definitiva', ou seja, aquele provimento jurisdicional que pode inspirar a imutabilidade. Na denominada 'tutela provisória', é possível obter uma proteção jurisdicional por um determinado lapso de tempo".
} 
dicotomia clássica "tutela de antecipada / tutela cautelar" ${ }^{\prime 6}$ se mostrou insuficiente para resolver os grandes problemas da contemporaneidade, o que fez com que fosse criada a tutela da evidência como uma forma de se dar mais um passo rumo à filosofia da ordinariedade.

As mudanças no NCPC, especialmente no que tange às tutelas provisórias, se propõem a ir ao encontro aos ideais da jurisdição contemporânea, razão pela qual podemos dizer que, hoje, temos um modelo de tutelas provisórias que se amolda aos anseios da contemporaneidade.

O contemporâneo não é a ruptura total do paradigma precedente, mas sim, a própria transição (e por isso repisamos a ideia de que não podemos nos propor a obter respostas prontas, já que estamos em uma fase de transição e de adequação de regras procedimentais para solução de conflitos).

Diante disso, pode-se afirmar que o NCPC não supera o cenário anterior de maneira abrupta, mas, pelo contrário, permite uma confluência de ideias e perspectivas, o que, sem dúvidas, torna ainda mais complexa a tarefa do operador do direito.

Não se trata do novo da superação ou da sucessividade. Trata-se, em verdade, do "novo da concomitância". O que se tem é um novo paradigma que continua atrelado à Constituição Federal, mas que exige mudanças que adequem o processo civil brasileiro às exigências da contemporaneidade ${ }^{8}$.

Com o NCPC, a tutela jurisdicional célere passa a ser um norte, um farol, um ideal perseguido por toda e qualquer reforma estrutural do direito - e o novo modelo de tutelas provisórias reflete isso. O legislador resgata a ideia que já era ventilada por Kazuo Watanabe na década de 80 e se recorda de que "a problemática do acesso à justiça não pode ser estudada nos acanhados limites do acesso aos órgãos jurisdicionais já existentes ${ }^{\text {* }}$.

A ordinariedade inerente ao $\mathrm{CPC} / 73$, por exemplo, violava amplamente o princípio do acesso à justiça quando permitia que o réu não titular do direito material gozasse do bem da vida até o final de um longo processo.

De acordo com a uma noção limitada de acesso à justiça, não haveria qualquer violação em permitir que o réu gozasse do bem da vida até o final do processo, já que o autor havia ingressado com a sua demanda perante os órgãos jurisdicionais - e isso seria suficiente para que não se violasse o princípio do acesso à justiça. No direito

\footnotetext{
${ }^{3}$ NEVES, Daniel Amorim Assumpção. Manual de Direito Processual Civil. 3a Ed. São Paulo: Gen / Método, 2011, p. 1137. "A doutrina majoritária divide a tutela de urgência em duas espécies: tutela cautelar e tutela antecipada”.

${ }^{7}$ Rui Cunha Martins contrapõe o novo da sucessividade ao novo da concomitância. Para o autor: "O novo da sucessividade trabalha com o conceito de superação. Segundo essa perspectiva, o que chega supera o antigo (...). Já o novo da concomitância trabalha com o conceito de contiguidade. Deste ponto de vista, ele permite a novidade pela viabilização de cruzamentos não antevistos entre elementos de várias ordens (...)”. MARTINS, Rui Cunha. O ponto cego do direito. The brazilian lessons. 2. Ed. Rio de Janeiro: Lumen Juris, 2011, p. 97.

${ }^{8}$ Quando a jurisdição passou, portanto, a se preocupar verdadeiramente com o acesso do cidadão à almejada justiça, o modelo anterior se tornou obsoleto ou, de acordo com Castanheira Neves, "entrou em crise". Esta crise se justifica porque não mais se admite uma jurisdição que não garanta de forma contundente o acesso do cidadão à justiça. NEVES, Castanheira. Entre o legislador, a sociedade e o juiz ou entre sistema, função e problema - os modelos actualmente alternativos da realização jurisdicional do direito. Boletim da Faculdade de Direito, v. LXXIV. Coimbra: Universidade de Coimbra, 1998, p. 02.

${ }^{9}$ WATANABE, Kazuo. Acesso à justiça e sociedade moderna. In: Participação e processo. São Paulo: Revista dos Tribunais, 1988,
} 
marcário, por exemplo, isso sempre foi manifesto.

E, por haver enorme dificuldade por parte do titular de um direito marcário em se comprovar e mensurar o dano irreparável (periculum in mora), sempre houve dificuldade em se fazer cessar eventual violação (antecipadamente), tornando intimidada a eficácia de direitos de propriedade assegurados pelo Instituto Nacional da Propriedade Industrial (INPI).

Isso comprova que o mero direito a um órgão jurisdicional, sem que sejam devidamente observadas as novas opções de acessibilidade do jurisdicionado, é insuficiente, principalmente quando a intangibilidade alcança bens jurídicos passíveis de proteção proprietária.

É esse mal que o NCPC, ao sistematizar a dinâmica das tutelas provisórias, se propõe a evitar (ou ao menos reduzir).

A dificuldade em obter a tutela jurisdicional de maneira efetiva, de forma a resguardar os bens jurídicos de violações, é muito comum em processos que envolvem violações a direitos marcários, que usualmente relacionam-se à constatação da lesão e reparação do dano. E, talvez por receio, muitos juízos preferiam manter o cenário vigente, ainda que esse cenário seja violador, a determinar, liminarmente, a cessação das violações.

O procedimento comum não mais basta para fins de efetivação da garantia de direitos: e aqui colocamos em foco o direito marcário, que sempre foi ferido de morte pelos juízes, sob o argumento de que eventual prejuízo causado por um ilícito poderia vir a ser solucionado em perdas e danos.

Ou seja, no âmbito do direito marcário, como os juízes costumam entender que se trata de questão meramente patrimonial (e que, portanto, teria importância reduzida se comparado a tutelas que envolvem questões existenciais), sempre se preferiu "converter" a tutela provisória em indenizatória.

Esse entendimento, porém, carece de sentido. A própria Lei da Propriedade Industrial (LPI - Lei no. 9.279/96) evidencia a importância da efetivação da proteção conferida aos bens jurídicos reconhecidos pelo INPI, tal como as marcas registradas. Basta uma breve leitura do artigo $209^{10}$ da mencionada lei para que se constate que o legislador tratou das tutelas preventiva e repressiva de formas bastante distintas ${ }^{11}$.

A verdade é que os juízes sempre agiram como se o titular de uma marca renomada (violada por terceiros sedentos em se apropriar indevidamente do fundo de comércio adquirido após anos de investimento) pudesse e devesse suportar todos os ônus do tempo no processo - tempo este que, no âmbito marcário é elevadíssimo. Basta lembrar que estamos diante de bens intangíveis normalmente pertencentes a empresários que

p. 128.

${ }^{10}$ Disponível: http://www.planalto.gov.br/ccivil_03/leis/L9279.htm. Acesso em 03 de janeiro de 2017

11 "As tutelas de urgência dos parágrafos $1^{\circ}$ e $2^{\circ}$ do artigo 209 da Lei de Propriedade Industrial podem, atualmente, ser definidas como tutelas inibitórias e de remoção de ato ilícito. Tais tutelas assumirão a natureza de tutela cautelar ou antecipada de acordo como foram formuladas no caso concreto (...).Se o pedido liminar for uma parcela do pedido de mérito da ação, ter-se-á uma tutela antecipada. Se tratar de medida conservativa de direito, ter-se-á tutela cautelar”. Propriedade Industrial Aplicada. Reflexões para o 
possuem poder econômico e que, por isso, conseguem impedir o andamento célere dos processos por meio da interposição de infindáveis recursos.

Esquece-se, no entanto, que a LPI ${ }^{12}$ trouxe a incumbência de se promover a repressão à concorrência desleal, cabendo ao Judiciário zelar pelo respeito, no dizer de Rubens Requião, “das regras que tipificam uma série de delitos que são praticados contra os titulares dos privilégios e registros e contra a concorrência, causando-lhes prejuízo, ou contra terceiros, os consumidores, que confiam nas garantias oferecidas pelo sistema da propriedade industrial, mas tem a sua boa-fé violada por atos predatórios" ${ }^{\prime \prime}$.

Em síntese, o presente trabalho objetiva examinar o novo modelo de tutelas provisórias e as suas repercussões no direito marcário, na esperança de que o Judiciário não mais legitimará violações incidentes sobre marcas alheias registradas, concedendo, enfim, tutelas provisórias para resguardar a higidez das marcas (logicamente, sempre que presentes os requisitos necessários para a sua concessão).

Para tanto, nos próximos capítulos, será concedida atenção especial ao exame da natureza jurídica dos direitos de propriedade industrial. Posteriormente, serão examinados os aspectos relevantes da evolução doutrinária no campo das tutelas provisórias e os elementos apresentados pelo NCPC para assegurar a proteção aos bens jurídicos de propriedade, principalmente as marcas e os direitos da propriedade industrial, conferindo maior segurança jurídica às transações comerciais.

\section{NATUREZA JURÍDICA DOS DIREITOS DA PROPRIEDADE INDUSTRIAL E O ATRIBUTO POLITICO DA PROPRIEDADE}

Antes de ingressar em debates processuais, é fundamental uma análise mais pormenorizada da natureza dos direitos da propriedade industrial. Somente assim, tornar-se-á viável aprofundar sobre a aplicabilidade do NCPC aos direitos em apreço.

Definir a natureza desses direitos intelectuais não é matéria puramente acadêmica, pois a natureza jurídica releva a forma de relacionamento entre as pessoas e os bens jurídicos envolvidos, possibilitando uma interpretação adequada das regras incidentes sobre os bens imateriais e uma maior clareza na aplicação analógica de outras leis, as quais regem direitos afins.

\footnotetext{
Magistrado. Brasília: 2013, p. 46-52. Disponível: http:/ /www.portaldaindustria.com.br. Acesso em 18 de dezembro de 2016.

${ }^{12}$ Art. 209. Fica ressalvado ao prejudicado o direito de haver perdas e danos em ressarcimento de prejuízos causados por atos de violação de direitos de propriedade industrial e atos de concorrência desleal não previstos nesta Lei, tendentes a prejudicar a reputação ou os negócios alheios, a criar confusão entre estabelecimentos comerciais, industriais ou prestadores de serviço, ou entre os produtos e serviços postos no comércio.

\ $1^{\circ}$ Poderá o juiz, nos autos da própria ação, para evitar dano irreparável ou de difícil reparação, determinar liminarmente a sustação da violação ou de ato que a enseje, antes da citação do réu, mediante, caso julgue necessário, caução em dinheiro ou garantia fidejussória.

${ }^{13}$ REQUIÃO, Rubens. Curso de Direito Comercial. Vol. 1. São Paulo: Saraiva, 2015, p. 209.
} 
Mais ainda, a determinação da natureza jurídica de um direito permite que o legislador assegure a regulamentação correta de um direito. Daí justifica-se a necessidade prática em definir a natureza jurídica dos institutos.

A necessidade de determinação da natureza jurídica das marcas ganha relevo atual e assume contornos práticos, pois o enquadramento correto dos sinais distintivos registráveis permite aos advogados recorrerem ao método de integração das normas jurídicas de institutos similares ou de incidência ampla para preencher lacunas na lei ou mesmo justificarem a eficácia desses direitos (como a abordagem do Código Civil ao enriquecimento ilícito e regramento do Código de Processo Civil para as tutelas provisórias).

Nesta seara, indaga-se qual seria a estrutura e os elementos fundamentais dos direitos imateriais que os levam a ter a natureza real e a classificá-los como propriedade intelectual, pois o instituto da propriedade sobre as coisas prende-se doutrinariamente no desenvolvimento do direito romano

A propriedade no Império Romano foi individualizada e hermeticamente analisada, sendo inconcebível a titularidade por uma pessoa e a exclusão do puro resultado da criação humana, vez que se caracteriza por ser incorpórea e carecer da materialidade necessária para estabelecer a relação jurídica entre o inventor e a sua criação intelectual.

Não obstante esta concepção primária do direito romano, deve-se relevar o fato de inexistir um conceito inflexível para o direito de propriedade que permite a inclusão de novos bens jurídicos passíveis de uma relação proprietária e exclusiva.

Neste ponto, salienta-se que, mesmo na Antiga Roma, o conceito de propriedade era influenciado por posicionamentos políticos prevalecentes e, portanto, modificadas pela necessidade de manutenção do poder político pelas elites do Império e pelos jurisconsultos que elaboraram novas técnicas e inseriram novos institutos jurídicos, tais como o traditio o o in iure cessio ${ }^{14}$.

Dessa forma, inexiste vedação para a ampliação do conceito de propriedade, conforme exigido pelas relações sociais e econômicas de uma determinada época, incluindo a inserção de novos bens jurídicos que não necessariamente se enquadram na estrutura jurídica "pura” da concepção romanística da propriedade.

Esse entendimento encontra-se melhor expresso nas palavras de nosso jurista Caio Mário ${ }^{15}$, como segue:

\footnotetext{
${ }^{14}$ Conforme Caio Mário da Silva Pereira, o desenvolvimento da propriedade no direito romano não foi linear, mas mesclado por necessidades políticas e pela reafirmação de domínio de outros povos. Como exemplo, este autor retrata o seguinte: "somente o cidadão romano poderia adquirir a propriedade; somente o solo romano podia ser seu objeto, uma vez que a dominação nacionalizava a terra conquistada. E a técnica da aquisição - mancipatio - um cerimonial tipicamente romano, restringia o fenômeno e limitava o domínio ex iure quiritium. Mais tarde estendeu-se o ius commercii aos estrangeiros, ampliou-se o fenômeno e limitava o domínio ex iure quiritium”. PEREIRA, Caio Mário da Silva. Instituições de Direito Civil. $8^{a}$ ed. Rio de Janeiro: Forense, 2004, p. 84.

${ }^{15}$ Idem.
} 
"A verdade é que a propriedade individual vigente em nossos dias, exprimindo-se embora em termos clássicos e usando a mesma terminologia, não conserva, todavia, conteúdo idêntico ao de suas origens históricas É certo que esse reconhece ao dominus o poder sobre a coisa; é exato que se o domínio enfeixa os mesmos atributos originários - ius utendi, fruendi et abutendi. Mas é inegável também que essas faculdades suportam evidentes restrições legais, tão frequentes e severas, que se vislumbra a criação de novas noções".

O enquadramento do direito inerente às concepções intelectuais em direito da propriedade intelectual, diante do até então exposto, não fere a doutrina dos direitos reais, pois a relação jurídica entre o autor/criador e a sua criação intelectual é similar àquela que rege o proprietário e o bem jurídico corpóreo, porquanto a natureza da relação recai mediata e diretamente sobre um bem jurídico, havendo a peculiaridade, no entanto, de o bem envolvido ser imaterial e intelectual.

Aliás, tal peculiaridade é devidamente regulamentada por leis especiais, tal como ocorre na Lei $n^{\circ}$. 9.279/96 (Lei da Propriedade Industrial), que estabelece o modo de aquisição e exercício, incluindo a limitação do bem jurídico no tempo e no espaço.

Outra peculiaridade relaciona-se ao que efetivamente é protegido, pois a propriedade no caso das marcas registradas visa a tutelar o fundo de comércio alcançado pelo maciço investimento realizado por um empresário e decorrente da capacidade magnética e notoriedade que uma marca exerce perante os consumidores.

Para determinar a noção proprietária sobre os direitos intelectuais, principalmente sobre as marcas registráveis, trataremos dos contornos elementares da propriedade privada, sendo que relevaremos 3 (três) aspectos estruturais, quais sejam:

\section{Objeto do Direito da Propriedade Intelectual}

Por ser o direito da propriedade um "direito civil patrimonial", este regula relações de conteúdo econômico e exige sempre que o objeto do direito ou da relação jurídica seja um bem jurídico.

Os bens jurídicos são tudo aquilo que possui um valor satisfativo da vontade humana e/ou que podem ser economicamente apreciáveis, sejam bens materiais ou imateriais. Pela sua valoração patrimonial e por acarretarem um aumento do patrimônio de seu titular, estes bens merecem amparo da ordem jurídica na concepção proprietária.

Entende-se assim que as criações intelectuais e marcas podem ser incluídas no rol dos bens jurídicos passíveis da relação jurídica entre as pessoas e os bens. Se analisarmos o desenvolvimento social e econômico humano, pode-se observar que este se relaciona intrinsecamente à capacidade inventiva do homem, sendo, aliás, largamente utilizada para diminuir o impacto das adversidades naturais na perpetuação humana.

Mesmo no caso das criações intelectuais sem aplicação direta na indústria e comércio, constata-se recentemente que estas se tornaram importantes instrumentos de transações internacionais e verdadeiros ativos 
empresariais que podem determinar o sucesso e a lucratividade das sociedades empresárias.

Mesmo sendo imateriais, as criações intelectuais e as marcas são verdadeiros bens jurídicos, constituindo-se assim patrimônio da pessoa (natural ou jurídica), merecedores da tutela jurídica em sua maior amplitude.

\section{Enquadramento como Tipo Proprietário}

As criações intelectuais se enquadram como tipo proprietário, já que são equiparadas aos bens móveis corpóreos $^{16}$ (concepção meramente jurídica). Ademais, as características desses bens e dos negócios jurídicos inerentes a eles são tratados em leis específicas denominadas Leis do Direito da Propriedade Industriale Lei do Direito Autoral.

Por serem equiparadas aos bens móveis, as criações intelectuais passam a integrar o objeto das relações inerentes ao exercício da propriedade. Tal entendimento é reforçado pelo reconhecimento constitucional ${ }^{17}$ da proteção conferida aos inventos e ás marcas, classificados como "Direitos e Garantias Fundamentais" bem como elementos constitutivos dos princípios que regem a ordem econômica constitucional brasileira.

Como ressalta Denis Borges Barbosa ${ }^{18}$, a Constituição Federal de 1988 expressa uma lídima declaração em favor da livre iniciativa e desenvolvimento econômico, ao inserir os direitos da propriedade intelectual, incluase aí as marcas, no rol dos direitos fundamentais individuais e também como princípios da ordem econômica.

\section{Atributos da Propriedade e os Direitos Intelectuais}

Os atributos da propriedade compóem-se de faculdades asseguradas aos titulares que recaem direta e imediatamente sobre os bens jurídicos envolvidos, sujeitando-os de modo completo e exclusivo ao poder de sua vontade. Isso significa que o titular do direito pode usar e dispor do bem jurídico como melhor entender, sem que haja dependência da prestação de ações por parte de outras pessoas.

Os atributos ou faculdades inerentes à propriedade podem ser explicitados sob a perspectiva estrutural e a funcional ${ }^{19}$. A estrutura dos atributos pode ser dividida sob a perspectiva econômica e jurídica, sendo que a

\footnotetext{
${ }^{16}$ Art. 50 (Lei no. 9.279/96): consideram-se bens móveis, para os efeitos legais, os direitos de propriedade industrial.

${ }^{17}$ Art. 5o (CRFB/88): a lei assegurará aos autores de inventos industriais privilégio temporário, para sua utilização, bem como proteção às criações industriais, à propriedade das marcas, aos nomes das empresas e a outros signos distintivos, tendo em vista o interesse social e o desenvolvimento tecnológico e econômico do país.

Art. 170 (CRFB/88): a ordem econômica, fundada na valorização do trabalho humano e na livre iniciativa, tem por fim assegurar a todos existência digna, conforme os ditames da justiça social, observados os seguintes princípios: (...) II - propriedade privada.

${ }^{18}$ BARBOSA, Denis Borges. Bases Constitucionais da Propriedade Intelectual. Revista da ABPI, no. 59. Rio de Janeiro: jul/ago 2002, p. 16-19.

${ }^{19}$ A perspectiva funcional foge ao escopo do presente artigo, mas traduz-se brevemente na necessidade de o exercício do bem jurídico atender ao bem-estar social (também denominada função social da propriedade). TEPEDINO, Gustavo. A Nova
} 
econômica reflete na possibilidade de o titular usufruir patrimonialmente do bem jurídico, ou seja, exercer o ius utendi, o ius fruendie o ius abutendi ${ }^{20}$.

A possibilidade de o titular usufruir, gozar e dispor do bem envolvido pode ser claramente observada nas marcas, quando o seu autor utiliza e explora diretamente uma marca no mercado e os frutos que esta gera (renome e fundo de comércio), ou mesmo quando é explorado por terceiros autorizados (licenciamento de marcas), relevando sempre a normalidade lógica do emprego da coisa.

Os atributos no direito da propriedade intelectual e das marcas são equiparados àqueles exercidos pela exploração corpórea (concepção material), sendo que a única diferença essencial se encontra em relação à natureza do seu objeto, que é imaterial - portanto, sofrem naturalmente as limitações inerentes ao seu conteúdo. Dentre essas limitações de uso está a temporalidade da propriedade sobre uma marca, que obedece aos períodos de validade estipulados nas respectivas Leis, e a territorialidade.

A perspectiva jurídica do direito de propriedade traduz-se na possibilidade do titular do bem jurídico em reaver a coisa (rei vindicatio) do terceiro que o utiliza indevidamente, garantindo desta forma a exclusividade sobre o seu uso e fruição. Sobre esse ponto, ressalta-se a disponibilidade dos procedimentos judiciais aos titulares de direito da propriedade intelectual, sejam as tutelas inibitórias como aquelas que visam o ressarcimento dos danos causados pelo usuário desautorizado, conforme especificadas no Código de Processo Civil.

Nesse cenário, é observado que os elementos e a estrutura delimitadora do direito sobre as criações intelectuais se inserem adequadamente nos contornos elementares da propriedade privada, pois estabelecem a existência e o exercício do bem jurídico envolvido em uma relação direta com o titular do direito.

\section{A MUDANÇA DE PARADIGMA: ANTECEDENTES E PRINCIPAIS ALTERAÇÕES PROMOVIDAS PELO NCPC NO REGIME DAS TUTELAS PROVISÓRIAS}

O processo civil brasileiro, repise-se, adota, como regra, uma filosofia da ordinariedade. Por outro lado a tutela provisória se relaciona de maneira íntima com a sumarização do processo, que é um ideal consagrado no NCPC.

A sumarização do processo surge efetivamente no Brasil em 1994, com a Lei 8.952/199421, a qual deu o pontapé inicial para do primeiro ciclo de reformas do $\mathrm{CPC} / 73$. Antes disso, não existia qualquer possibilidade de se obter o bem da vida no curso do processo de conhecimento.

Propriedade (O seu Conteúdo Mínimo, entre o Código Civil, a Legislação Ordinária e a Constituição). Revista Forense 306, págs. 73 a 78 .

${ }^{20}$ DIAS, José Carlos Vaz e. New Dress Code for Business Transactions in Brazil: Essentials and Peculiarities of Trademarks in the Spotlight. In: CALBOLI, Irene; WERRA, Jacques (ed.) The Law and Practice of Trademark Transactions: a Global and Local Outlook. Edward Elgar Publishing, 2015. 
Com o surgimento da norma do artigo 273 do CPC/73, passou-se a não mais ser necessária, naqueles casos que preenchessem os requisitos legais, a absurda espera de uma decisão final sem que a parte infringida fizesse jus a qualquer tutela jurisdicional, a tempo, para a proteção de seus bens jurídicos e restabelecimento do status quo ante.

Impulsionado pelo lema justiça tardia não éjustiça e pelo processo de fortalecimento da democracia e do Estado Democrático de Direito no Brasil (expressos no ideal de segurança jurídica e na jurisdição regular e efetiva disponibilizada em tempo razoável e adequada para garantir-se o direito à propriedade e à dignidade humana) ${ }^{22} \mathrm{o}$ legislador pátrio possibilitou a antecipação dos efeitos da sentença de mérito, concedendo àquele que formula o pleito antecipatório aquilo que, ordinariamente, ele somente faria jus ao final do processo.

O legislador, enfim, deu conta de que a atividade jurisdicional deve por em foco o resultado final e a realização do direito material (e não a burocracia procedimental), o que seria uma exigência do princípio da instrumentalidade das formas. Ou seja: de nada adianta assegurar a idoneidade da marcha processual se o bem jurídico em litígio não for devidamente resguardado ${ }^{23}$.

Em outras palavras, percebe-se que a observância das regras técnicas não deve ter um fim em si mesmo, o que fez com que Marco Félix Jobim ressaltasse que "a aplicação do processo civil brasileiro não poderia mais se conformar com a mera técnica, baseando-se unicamente em formas" ${ }^{24}$.

O processo civil, com a onda de reformas que revolucionou o sistema processual anteriormente vigente, passa a não mais existir sem qualquer preocupação com o seu fim. Em outras palavras, o processo civil deixa de ser um mero protocolo de exigências, passando a ser um efetivo instrumento garantidor do direito material.

O direito processual, mais do que uma atividade burocrática de aplicação a serviço do direito material, passa a ser enxergado como um instrumento concretizador de direitos. Com isso, a utilidade do processo é

\footnotetext{
${ }^{21}$ Disponível: https://www.planalto.gov.br/ccivil_03/leis/L8952.htm. Acesso em 20 de novembro de 2016.

${ }^{22}$ NÓBREGA, Guilherme Pupe da. O CPC/2015 e a Tutela Provisória de Urgência Antecipada. In: Processo Civil em Debate. Organizado por Janete Ricken Lopes de Barros e Guilherme Pupe da Nóbrega. IDP. Brasília: 2015, p 59. Disponível: http://www.idp.org.br/component/docman/doc_download/906-direito-processual-civil. Acesso em 3 de janeiro de 2017.

23 "Ao proibir a autotutela e avocar para si o monopólio da jurisdição, função estatal que retira seu fundamento, antes, da soberania, o Estado assume um compromisso: o de prestar a tutela a que se comprometeu, tutela essa que deverá ser efetiva, sob pena de ser inócua, por frustrar seu intento originário — a pacificação social —, e de deslegitimar o Estado. O raciocínio é simples: "o dever imposto ao indivíduo de submeter-se obrigatoriamente à jurisdição estatal não pode representar um castigo"; ao revés, essa imposição "deve ter como contrapartida necessária o dever do Estado de garantir a utilidade da sentença, a aptidão dela de garantir, em caso de vitória, a efetiva e prática concretização da tutela." De tão importante, a previsão dessa efetividade foi alçada a status constitucional, tendo morada fixa no artigo $5^{\circ}$, inciso XXXV, que trata da inafastabilidade jurisdicional. Ao jurisdicionado não interessa ter somente razão ou ter seu direito apenas declarado — ressalva feita às declaratórias. Ao jurisdicionado interessa, sim, ver seu direito, reconhecido em maior ou menor grau, efetivado. Ter a si entregue o bem da vida, ver correspondido, em concreto, o que abstratamente constou friamente do papel, da decisão judicial. Acontece que o processo por meio do qual se exercita o direito de ação, meio de provocação do Estado para que, saído da inércia, preste a jurisdição, mais que veículo da pretensão material55, é conjunto de relações jurídicas de que são titulares e destinatários recíprocos os seus sujeitos: juiz, autor e réu. Disso decorre a necessidade de normas que instrumentalizem, regulem e garantam esses mesmos direitos: as normas processuais". Idem, p. 63. ${ }^{24}$ JOBIM, Marco Félix. Cultura, escolas e fases metodológicas do processo. Porto Alegre: Livraria do Advogado, 201 1, p. 90.
} 
fundamental, condicionando, por vezes, a existência do próprio direito material.

Essa ideia encontra-se muito bem explicitada na obra de Dinamarco. Ao focar no aspecto positivo da instrumentalidade das formas, o autor destaca os seus "quatro pontos sensíveis" ${ }^{25}$ : (i) o acesso à justiça; (ii) o modo-de-ser do processo; (iii) justiça das decisões e (iv) utilidade das decisões.

Em síntese, pode-se afirmar que, deixou-se de lado o formalismo exacerbado que inquinava o processo e deu-se foco à garantia efetiva dos bens jurídicos, ou seja, daqueles direitos potencialmente ou efetivamente passíveis de valor para uma sociedade, assegurando assim a efetividade do direito material ${ }^{26}$.

A utilidade das decisões tem absolutamente tudo a ver com o regime das tutelas provisórias que, à época do $\mathrm{CPC} / 73$, se restringiam às chamadas tutelas de urgência.

As tutelas de urgência surgem no intuito de evitar a ocorrência daquilo que Enrico Finzi chamava de dano marginal em sentido estrito. Antônio do Passo $\mathrm{Cabral}^{27}$ muito bem explica a doutrina de Enrico Finzi, ao aduzir que:

"Em verdade, a demora na solução do litígio impõe a todos os litigantes um prejuízo: autor e réu perdem simultaneamente em razão do prolongamento injustificado da lide. Trata-se de um dano que não decorre da derrota em relação à pretensão deduzida, mas um "dano marginal", na feliz expressão que foi popularizada na doutrina italiana por Enrico Finzi. O dano marginal é aquele que sofrem os litigantes em razão de deficiência na tramitação dos processos, e esta demora afeta a ambos, autor e réu, vencedor e vencido".

O dano moral em sentido estrito, em suma, tem a ver com a demora processual, a qual é capaz de trazer malefícios imensuráveis e, por vezes, irreversíveis aos litigantes de um processo, principalmente para aquele que possui razão e é obrigado a ver seu direito desprovido de qualquer proteção ${ }^{28}$.

Antes das reformas processuais, o problema da demora processual era resolvido por meio de cautelares satisfativas, o que, com todas as vênias, era um equívoco, indo de encontro ao próprio objetivo da tutela cautelar, qual seja: assegurar o resultado útil de um processo.

Após 1994, o problema é amenizado - porém não totalmente superado, pois muitos ainda não

\footnotetext{
${ }^{25}$ DINAMARCO, Cândido Rangel. Escopos políticos do processo. In: Participação e processo. São Paulo: Revista dos Tribunais, 1988, p. 117.

${ }^{26}$ Nesse sentido: "A satisfação de um direito, desde Roma, era miragem distante dos olhos do autor que ingressava em juízo para ver seu direito primeiramente reconhecido e, somente depois — no mais das vezes, muito depois —, realizado de fato. A satisfação dependia da formação de coisa julgada, sem a qual não se dava início à prática de atos de execução, de satisfação. A cisão rígida entre as tutelas impedia a sua prestação concomitante. O processo de cognição plena, voltado para o cumprimento da tutela jurisdicional ordinária, por sua vocação genética, não conceberia medidas liminares (ou quaisquer outros provimentos antecipatórios), que romperiam com a sua ordinariedade. Natural que assim fosse. A justiça imediata é impossível. Porque reside na certeza, a cognição exauriente é condicionada a caminho mais longo, tempestuoso, que não se compadece, porém, com as notas de urgência de que se revestem determinados casos. Casos esses em que a efetividade da jurisdição fica comprometida, ou pelo risco da tardividade, ou pelo risco da infrutuosidade da prestação jurisdicional. Hipóteses carentes da necessária adequação do procedimento à tutela diferenciada, porque urgente — protetiva do direito". NÓBREGA, Guilherme Pupe da. Op. cit., p. 65.

${ }^{27}$ CABRAL, Antônio do Passo. A duração razoável do processo e a gestão do tempo no projeto de novo código de processo civil. In: FREIRE, Alexandre [et al] (Coord.). Novas tendências do processo civil. Salvador: Jus Podivm, 2013, p. 76.
} 
conseguiam distinguir com exatidão a tutela cautelar da antecipada (o que perpetuou alguns processos cautelares que tinham como único objetivo a antecipação de tutela) e, por (incontáveis) vezes, os seus requisitos eram confundidos. Vejamos um mero exemplo:

“AGRAVO DE INSTRUMENTO. INDEFERIMENTO DE TUTELA ANTECIPADA. PROCESSO CAUTELAR. PROVIDÊNCIA DE CUNHO SATISFATIVO. AUSÊNCIA DE VEROSSIMILHANÇA. 1. O pleito de anulação do leilão por via cautelar constitui providência de cunho satisfativo, o que configura inadequação da via eleita. 2. Ausência de elementos necessários à comprovação das ilegalidades apontadas no procedimento de execução extrajudicial do imóvel. 3. Afastada a verossimilhança da alegação. 4. Recurso desprovido". (Grifos Nossos)

(TRF 2; AI 2007.02.01.007111-0; oitava Turma Especializada; Relator: Desembargador Federal Poul Erik Dyrlund; Julgamento: 13/05/2008)

$\mathrm{O}$ recurso de agravo de instrumento cuja ementa se encontra acima transcrita, julgado em 2008 (portanto, 14 anos após a Lei 8.952/1994), retrata com clareza o cenário de caos que reinava em terra brasilis mesmo após as reformas, problemas este que o legislador somente veio a solucionar (ou pelo menos tentar - o tempo irá nos dizer) com o NCPC.

O NCPC continua abraçando a distinção entre tutela antecipada e tutela cautelar, mas deixa claro que estamos diante de dois instrumentos distintos. Porém, no intuito de facilitar a vida do operador do direito, o diploma processual uniformiza os seus pressupostos.

Fato é que, hoje, com o NCPC, temos uma distinção muito evidente, o que nos permite concluir que tudo aquilo que acautela não satisfaz, visto que a tutela satisfativa atua no plano fático e entrega bem da vida (antecipadamente), enquanto a tutela cautelar assegura o resultado útil do processo (cautelarmente).

A tutela provisória é uma das grandes vedetes do NCPC (dentre muitas outras criações e aperfeiçoamentos), tendo o novo diploma trazido consigo significativas mudanças na sua forma de ser, como as seguintes alterações: (i) extinção do processo cautelar e dos procedimentos das medidas cautelares inominadas; (ii) uniformização dos requisitos para a concessão das tutelas de urgência; (iii) estabilização da tutela satisfativa.

Por uma escolha didática, enfrentaremos somente as mudanças (ii) e (iii) acima mencionadas, as quais se revelam fundamentais para a continuidade da análise do tema eleito, posto que exercem influência imediata sobre o direito marcário.

\section{Uniformização dos requisitos para a concessão das tutelas de urgência: uma esperança para os titulares de direitos marcários violados}

As tutelas de urgências são espécie do gênero tutela provisória, sendo que estas podem ser cautelares ou

\footnotetext{
28 “O autor com razão é prejudicado pelo tempo da justiça na mesma medida em que o réu sem razão é beneficiado”. MARINONI, Luiz Guilherme. Teoria geral do processo. 2. Ed. São Paulo: Revista dos Tribunais, 2007, p. 190.
} 
satisfativas ${ }^{29}$. As tutelas de urgência reproduzem, portanto, o sistema dicotômico existente no CPC/73: tutelas antecipadas vs. cautelares.

Todavia, em seu artigo 300, o NCPC uniformiza os requisitos necessários para a concessão das referidas tutelas de urgência, o que cria um sistema muito mais seguro, diminuindo a possibilidade de confusão pelos operadores do direito.

Daniel Assumpção ${ }^{30}$ muito bem destaca as diferenças que existiam no $\mathrm{CPC} / 73$ em relação aos requisitos para a concessão das tutelas de urgência.

Em um primeiro momento, o autor trata da necessidade de comprovação da probabilidade do direito. Enquanto na tutela cautelar exigia-se o fumus boni iuris, na tutela antecipada era imperiosa a comprovação da inequívoca verossimilhança das alegações:

"Um dos requisitos para a concessão da tutela antecipada é a prova inequívoca da verossimilhança da alegação, segundo previsão expressa do art. 273, caput, do CPC. Para a tutela cautelar, um dos requisitos para a sua concessão é o fumus boni iuris. Apesar de ambos se situarem no plano da probabilidade do direito, é inegável que entre eles existe uma diferença fundamental".

Essa distinção, por si só, causava confusão, sendo pouco prática, haja vista a enorme dificuldade que o jurista tinha de aferir o grau de probabilidade de um direito: se a probabilidade configurava fumus boni iuris (um grau inferior de probabilidade) ou prova inequívoca (grau mais intenso). Isso porque, a prova inequívoca, em tese, estaria mais próxima do juízo de certeza do que o fumus boni iuris.

\footnotetext{
29 "A tutela de urgência pode ser cautelar ou satisfativa (esta também conhecida como tutela antecipada de urgência), nos termos do que dispõe o art. 294, parágrafo único. Chama-se tutela cautelar à tutela de urgência do processo, isto é, à tutela provisória urgente destinada a assegurar o futuro resultado útil do processo, nos casos em que uma situação de perigo ponha em risco sua efetividade. Pense-se, por exemplo, no caso de um devedor que, antes de vencida sua dívida, tente desfazer-se de todos os bens penhoráveis. Não obstante a alienação desses bens não comprometa a existência do direito de crédito, certo é que o futuro processo de execução não será capaz de realizar na prática o direito substancial do credor se não houver no patrimônio do devedor bens suficientes para a realização do crédito. Verifica-se, aí, uma situação de perigo para a efetividade do processo, isto é, para a aptidão que o processo deve ter para realizar na prática o direito substancial que efetivamente exista (podendo-se falar, aí, em perigo de infrutuosidade). Em casos assim, faz-se necessária a previsão de mecanismos processuais destinados a assegurar a efetividade do processo, garantindo a futura produção de seus resultados úteis. A tutela provisória cautelar, portanto, não é uma tutela de urgência satisfativa do direito (isto é, uma tutela de urgência capaz de viabilizar a imediata realização prática do direito), mas uma tutela de urgência não satisfativa, destinada a proteger a capacidade do processo de produzir resultados úteis. Na hipótese que acaba de ser figurada como exemplo a tutela provisória deverá consistir na apreensão de tantos bens do devedor quantos bastem para assegurar a futura execução. Já a tutela de urgência satisfativa (tutela antecipada de urgência) se destina a permitir a imediata realização prática do direito alegado pelo demandante, revelando-se adequada em casos nos quais se afigure presente uma situação de perigo iminente para o próprio direito substancial (perigo de morosidade). Pense-se, por exemplo, no caso de alguém postular a fixação de uma prestação alimentícia, em caso no qual a demora do processo pode acarretar grave dano à própria subsistência do demandante. Para casos assim, impõe-se a existência de mecanismos capazes de viabilizar a concessão, em caráter provisório, da própria providência final postulada, a qual é concedida em caráter antecipado (daí falar-se em tutela antecipada de urgência), permitindo-se uma satisfação provisória da pretensão deduzida pelo demandante. Ambas as modalidades de tutela de urgência, portanto, têm como requisito essencial de concessão a existência de uma situação de perigo de dano iminente, resultante da demora do processo (periculum in mora). Este perigo pode ter por alvo a própria existência do direito material (caso em que será adequada a tutela de urgência satisfativa) ou a efetividade do processo ("hipótese na qual adequada será a tutela cautelar"). CÂMARA, Alexandre Freitas. O Novo Processo Civil Brasileiro, 2a edição. Rio de Janeiro: Atlas, 2016, 156.

${ }^{30}$ NEVES, Daniel Amorim Assumpção. Op. cit., p. 1.142.
} 
Na prática, era quase impossível aferir com exatidão a distinção: ao se depararem com um pedido de antecipação de tutela, os magistrados precisavam analisar se haveria um fumus boni iuris mais intenso ou se estava diante tão somente de um fumus boni iuris que serviria para a concessão de uma medida cautelar, mas que, para a antecipatória, era insuficiente.

Em vista da dificuldade, era comum que os advogados pleiteassem quaisquer das medidas urgentes sempre comprovando os mesmos requisitos, independentemente de estar diante de tutela cautelar ou antecipada.

Igualmente, os magistrados, ao tomarem as suas decisões, seguiam a mesma linha e decidiam sem atentar para a distinção: analisava-se a probabilidade de o direito ser titularizado pela parte que pleiteava o pleito de urgência. Se existia probabilidade para a concessão de medida cautelar, também existiria para o deferimento de um pleito antecipatório.

No âmbito marcário não era diferente. Com isso, o grau de probabilidade costumava não ser observado pelos juízes quando da concessão dessas tutelas. Por essa razão, não raro, se falava somente em fumus boni iuris, seja para conceder uma tutela cautelar, seja para conceder uma tutela antecipada ${ }^{31}$.

É importante ressaltar que, em termos de proteção do direito material envolvido, o equívoco perpetrado por alguns operadores do direito ao elencar os requisitos para a concessão de uma determinada tutela de urgência não era relevante a ponto de obstar tal proteção.

No dia-a-dia forense, a comunidade jurídica já havia promovido a unificação dos requisitos que devem estar presentes para que uma tutela de urgência venha a ser concedida, o que tornava a necessidade de comprovação da prova inequívoca do direito (insculpida no artigo 273 do $\mathrm{CPC} / 73$ ) um preceito simbólico ${ }^{32}$, o que prejudicial para fins de efetividade.

O segundo requisito para a concessão das tutelas de urgência, por outro lado, não causava tanto problema, já que o periculum in mora era o mesmo em qualquer hipótese. Assim preceitua Alexandre Câmara ${ }^{33}$ :

\footnotetext{
${ }^{31}$ AGRAVO DE INSTRUMENTO. PROPRIEDADE INTELECTUAL. MARCAS. USO INAUTORIZADO DE WEBSITE, TRADE DRESS, DESENHO INDUSTRIAL E SLOGANS, CAUSA CONFUSÃO NOS CONSUMIDORES QUANTO A ESTAR A RÉ LICENCIADA PELA AUTORA. DANO DE DILUIÇÃO DA MARCA E PERDA DE CLIENTELA. CONCORRÊNCIA DESLEAL. LIMINAR QUE ATENDE AOS REQUISITOS DO FUMUS BONI IURIS, PERICULUM IN MORA. PROVA DOCUMENTAL QUE A NÍVEL DE COGNIÇÃO SUMÁRIA DEMONSTRA A VEROSSIMILHANÇA DAS ALEGAÇÕES. DECISÃO LIMINAR AMPARADA NA PROVA DOS AUTOS E NA LEI 9.279/96. CORRETA A DECISÃO. APLICÁVEL A SÚMULA 59 TJRJ. NEGA-SE SEGUIMENTO AO RECURSO NA FORMA DO ART. 557 \& 1 DO CPC (TJRJ; AI 00661691820108190000; Décima Oitava Câmara Cível; Relator: Helena Cândida Lisboa Gaede; Julgamento: 17/12/2010).

${ }^{32}$ A palavra "simbólica" é adotada por Marcelo Neves. De acordo com o autor, uma Constituição simbólica se caracteriza pela falta de eficácia das suas normas. O simbolismo constitucional, segundo Marcelo Neves, seria uma prevalência da função simbólica em detrimento da concretização normativa de seus preceitos. Essa ideia também pode ser perfeitamente aplicada à legislação infraconstitucional, notadamente o Código de Processo Civil. NEVES, Marcelo. Constituição simbólica. Pernambuco: Martins Fontes, 1998 .

${ }^{33}$ CÂMARA, Alexandre Freitas. Op. cit, p. 146.
} 
"Ambas as modalidades de tutela de urgência, portanto, têm como requisito essencial de concessão a existência de uma situação de perigo de dano iminente, resultante da demora do processo (periculum in mora). Este perigo pode ter por alvo a própria existência do direito material (caso em que será adequada a tutela de urgência satisfativa) ou a efetividade do processo (hipótese na qual adequada será a tutela cautelar)”.

De acordo com a doutrina, as tutelas satisfativas ainda continuariam exigindo um requisito extra para a sua concessão: possibilidade de reversibilidade da medida ${ }^{34}$.

É possível afirmar que a uniformização dos requisitos para fins de concessão das tutelas de urgência ${ }^{35}$, na verdade, é muito mais do que uma mera unificação: trata-se de uma simplificação procedimental, sendo esta fundamental para a escorreita aplicação das normas processuais civis.

No âmbito marcário, tal simplificação adquire importância sem tamanho, passando-se a confiar que a tutela marcária também se tornará mais efetiva.

O processo civil parece nunca ter, de fato, se importado com tutela preventiva dos direitos da propriedade industrial, relegando a solução final sempre para a faceta indenizatória. Parece evidente que essa "nãoimportância” seja, na verdade, medo, haja vista se tratar de tema que ganhou importância recentemente e vem ganhando relevância cada vez maior.

Some-se a isso o fato de que o Poder Judiciário costuma entender que disputas marcárias envolvem poder econômico, razão pela qual a tutela ressarcitória poderia vir a resolver todos os problemas.

Acontece que, por muitas das vezes, o que o titular de um direito da propriedade industrial deseja prevenir um dano, seja para (i) proteger a sua marca (ou qualquer outro direito correlato) no âmbito mercadológico, seja (ii) pela dificuldade que as empresas enfrentam em quantificar eventuais perdas e danos.

A afirmação de que o Judiciário não se importa com a tutela preventiva de direitos marcários pode ser facilmente corroborada por intermédio de uma breve leitura do trecho do acórdão abaixo transcrito ${ }^{36}$ :

"A questão em litígio é extremamente importante e, ao que parece, não foi ainda suficientemente abordada na jurisprudência, tanto assim que nenhuma das partes trouxe aos autos qualquer aresto que permitisse entrever a jurisprudência dos Tribunais Pátrios sobre a

\footnotetext{
34 “Além dos dois requisitos já examinados (probabilidade de existência do direito e perigo de dano iminente), a tutela de urgência satisfativa exige mais um requisito para ser concedida. Trata-se de um requisito negativo: não se admite tutela de urgência satisfativa que seja capaz de produzir efeitos irreversíveis (art. 300, \$ 3o). É que não se revela compatível com uma decisão baseada em cognição sumária (e que, por isso mesmo, é provisória) a produção de resultados definitivos, irreversíveis. Pense-se, por exemplo, em uma decisão concessiva de tutela provisória que determinasse a demolição de um edifício ou a destruição de um documento. Pois em casos assim é, a princípio, vedada a concessão da medid0a”. CÂMARA, Alexandre Freitas. Op. cit., p. 146.

35 “(...) o nível de profundidade da cognição a ser desenvolvida pelo juiz para proferir a decisão acerca do requerimento de tutela de urgência passa a ser sempre o mesmo, seja a medida postulada de natureza cautelar ou satisfativa. Tanto num caso como no outro deve a decisão ser apoiada em cognição sumária, a qual leva à prolação de decisão baseada em juízo de probabilidade (fumus boni iuris). O que distingue os casos de cabimento da tutela de urgência cautelar daqueles em que cabível a tutela de urgência satisfativa é o tipo de situação de perigo existente: havendo risco de que a demora do processo produza dano ao direito material, será cabível a tutela de urgência satisfativa; existindo risco de que da demora do processo resulte dano para sua efetividade, caberá tutela de urgência cautelar". Idem.

36 TJRJ; agravo de instrumento nº. 0010622-90.2010.8.19.0000; Décima Sexta Câmara Cível; Relator: Des. Mario Robert Mannheimer; Julgamento: 27/07/2010.
} 
matéria, o que recomenda que não se adote qualquer medida antecipatória no presente feito, até mesmo para evitar prejulgamento. Cumpre ressaltar que a Ré é empresa de grande porte, que aparentemente tem idoneidade financeira para fazer frente a uma eventual condenação, nada tendo sido afirmado em contrário, bem como que a atual Lei da Propriedade Industrial proporciona ampla indenização aos prejudicados por violações aos direitos de propriedade industrial e por atos de concorrência desleal, inclusive no tocante aos lucros cessantes, o que afasta ou pelo menos atenua o periculum in mora (...)".

Com todas as vênias, independentemente da existência ou não dos requisitos necessários para a concessão da tutela antecipada requerida no caso que embasa o acórdão transcrito acima, dois grandes equívocos foram perpetrados na fundamentação utilizada.

Primeiro: negar a concessão de uma tutela antecipada sob a justificativa de que um tema não foi suficientemente debatido na jurisprudência é simplesmente inaceitável. Isso quer dizer que direitos já debatidos pelos Tribunais merecem maior proteção do que aqueles veiculados em um leading case?

É de uma clareza solar (tanto sob a égide do CPC/73 quanto do NCPC) que, caso se encontrem preenchidos os requisitos que fundamentam a concessão de uma tutela de urgência, esta deverá ser concedida, não sendo a inexistência de debate prévio um argumento válido e legítimo. Caso contrário, violar-se-á o princípio da proibição do non liquet ${ }^{37}$, ainda que de forma escamoteada.

A lei processual não elenca - e jamais elencou - como requisito a necessidade de prévio debate por outras Cortes a respeito do tema objeto de uma tutela de urgência. Pensar assim amesquinha o direito material que fundamenta um pedido de tutela de urgência, deixando-o sem proteção.

Segundo: a idoneidade financeira que faça frente a uma condenação não obsta a concessão de uma tutela preventiva. A despeito de estarmos diante de duas faces da mesma moeda, a tutela preventiva e a tutela ressarcitória são absolutamente distintas: enquanto esta busca a reparação de um dano que não se conseguiu evitar, aquela objetiva prevenir a ocorrência de um dano evitável.

O ressarcimento é um caminho secundário. E não é por outro motivo que, apesar de caber ao Poder Judiciário colocar o titular de um direito violado na mesma posição que estaria se não houvesse violação do direito tutelado, "o processo civil brasileiro nunca fez valer essa máxima no âmbito da propriedade industrial". Isso porque, prossegue o autor: "a construção pretoriana tratou de abrir seus próprios caminhos na tentativa de burlar

\footnotetext{
37 “A proibição do non liquet é um axioma raramente contestado ou debatido no direito brasileiro. O Superior Tribunal de Justiça (STJ) e o Supremo Tribunal Federal (STF) já se posicionaram, ambos, no sentido da proibição do non liquet, sem realizarem maiores indagações a respeito do acerto ou do equívoco dessa conclusão. Da jurisprudência do STF colhe-se trecho do voto do ministro Carlos Ayres Britto no qual se consignou que: 'se ao Legislativo não se pode impor a obrigação de legislar, ao Judiciário se impõe, sim, a obrigação de julgar. É proibida, no âmbito do Judiciário, a formulação daquele juízo de non liquet, de não resolver a causa. $\mathrm{O}$ juiz de qualquer instância, o Tribunal de qualquer natureza tem que solver a questão, liquidar a questão para corresponder a esse prestígio máximo que a Constituição lhes deu ao dizer que a lei não excluirá da apreciação do Poder Judiciário lesão ou ameaça a direito’”. KOATZ, Rafael Lorenzo. A proibição do non liquet e o princípio da inafastabilidade do controle jurisdicional. Revista de Direito Administrativo. Rio de Janeiro: v. 270, p. 171-205. Disponível: http://bibliotecadigital.fgv.br/ojs/index.php/rda/article/view/58741/57534. Acesso em 29 de dezembro de 2016.
} 


\title{
um sistema descomprometido em oferecer instrumentos idôneos à tutela da propriedade industrial ${ }^{38}$.
}

Nesse mesmo diapasão, Luiz Fernando Pereira ressalta a importância das tutelas preventivas para o direito marcário e ressalta que se trata de um direito que não guarda relação com a tutela ressarcitória ${ }^{39}$.

Enfim, apesar dos anos de menosprezo da jurisprudência, o NCPC trouxe uma esperança para os titulares de direitos marcários.

Espera-se, de uma vez por todas, que o ideal de efetividade embutido no diploma processual de 2015 mude a mentalidade dos julgadores, a fim de que estes possam perceber a importância da tutela preventiva para a proteção marcária.

\section{Estabilização da tutela satisfativa: concretização da justiça e celeridade com observância do devido processo legal}

Outra alteração substancial apta a gerar inequívocos ganhos ao titular de um direito marcário diz respeito à possibilidade de estabilização da tutela antecipada. Em breve síntese, se a parte obtiver uma tutela antecipada e a parte contrária não interpuser recurso, esta se tornará estável, somente havendo possibilidade de reversão caso seja proposta demanda própria.

Sobre a estabilização da tutela antecipada, uma das grandes novidades do NCPC, Alexandre Câmara ${ }^{40}$ assim doutrina:

\begin{abstract}
“(...) concedida a tutela de urgência satisfativa nos termos do art. 303 (isto é, com base em uma petição inicial incompleta em razão da extrema urgência existente ao tempo da propositura da demanda) e não tendo o réu interposto recurso contra a decisão concessiva da tutela antecipada, esta se tornará estável, devendo o processo ser extinto sem resolução do mérito (art. 304, $\$ 1^{\circ}$ ). O recurso interposto por assistente simples do réu também impede a estabilização da tutela antecipada, salvo se o réu expressamente se manifestar no sentido de que prefere a estabilização (FPPC, enunciado 501). A decisão concessiva da tutela de urgência estável não faz coisa julgada (isto é, não se torna imutável e indiscutível), como estabelece expressamente o art. $304, \$ 6^{\circ}$, o que é consequência inexorável do fato de ter sido ela proferida com apoio em cognição sumária e não em cognição exauriente (sendo esta essencial para que a decisão judicial alcance a autoridade de coisa julgada). Seus efeitos, porém, se tornam estáveis e só podem ser afastados por decisão judicial que a desconstitua, proferida em demanda proposta por alguma das partes em face da outra ( $a r t .304, \$ 3^{\circ}$ e $\$ 6^{\circ}$, in fine). Não havendo formação de coisa julgada, não se admite, em hipótese alguma, a ação rescisória como mecanismo de impugnação da decisão que tenha declarado estabilizada a tutela antecipada (FPPC, enunciado 33)".
\end{abstract}

\footnotetext{
${ }^{38}$ PEREIRA, Luiz Fernando. Tutela jurisdicional da propriedade industrial. Aspectos processuais da Lei 9.279/1996. São Paulo: RT, 2006, p. 22.

39 "O discurso da insuficiência da tutela ressarcitória no âmbito do Direito Industrial decorre de alguns argumentos elementares. Primeiro porque será recorrente a insuficiência da reparação do dano, pois pode subsistir um benefício econômico, derivado diretamente do ilícito, em favor daquele que praticou a lesão. (...) Depois, é preciso reconhecer que a admissão da tutela ressarcitória no caso de direitos não patrimoniais é o mesmo que aceitar, por exemplo, que a indevida utilização de marca seja autorizada mediante posterior pagamento. Trata-se, na prática, da autorização para a compra de danos”. Idem.

${ }^{40}$ CÂMARA, Alexandre Freitas. Op. cit., p. 161.
} 
No CPC/73, não havia tal previsão, tendo a tutela antecipada um caráter de provisoriedade. Sendo assim, ainda que a parte prejudicada pela concessão de uma tutela antecipada sequer se manifestasse nos autos do processo, o trâmite processual ocorreria de maneira ordinária até a prolação de uma sentença de mérito confirmando a tutela anteriormente concedida.

O regime anterior, por ser excessivamente formalista, obrigava o titular de um direito material a aguardar até o final do processo para finalmente poder usufruir, com caráter de definitividade, de um determinado bem da vida - ainda que a outra parte sequer intervisse no processo.

No caso marcário, tal questão se tornava ainda mais sensível, principalmente se considerarmos o valor agregado que certas marcas possuem (valor este que, em muitos casos, é inestimável). Muitas das vezes, o titular de uma data marca, mesmo possuindo uma antecipação de tutela em seu favor, por não saber o que poderia ocorrer até o final do processo, ficava com receio de usufruir o seu próprio bem.

Essa forma burocrática de se enxergar o processo vem sendo alterada e o NCPC nos faz crer que esse enfraquecimento do formalismo exacerbado é uma realidade inexorável. Sobre as mutações que vem atingindo o processo, Barbosa Moreira destaca que "se toma consciência cada vez mais clara da função de instrumento do processo e da necessidade de fazê-lo desempenhar de maneira efetiva o papel que lhe toca" ${ }^{\text {"11. }}$.

A estabilização da tutela antecipada para o direito marcário (e ousamos dizer que para a propriedade industrial como um todo) é uma grande conquista, visto existir uma necessidade real de se prevenir possíveis violações de forma eficaz, em oposição ao mero ressarcimento, o que se justifica em função da própria natureza intangivel das marcas.

Aliás, falando em ressarcimento, em muitos casos, a não antecipação de tutela representa uma intenção dos juízes em "resolver o caso em perdas e danos", opção esta que traz em seu bojo efeitos deletérios ao titular de uma marca: além de não conseguir o pleito antecipatório (deixando de fruir de um bem que the pertence), esbarra em uma dificuldade, tendo em vista que a comprovação de danos materiais é tarefa árdua.

Esse fato nos remete à compreensão errônea e injustificável de que a concessão da tutela antecipada e indenização do titular da marca que teve os seus direitos proprietários infringidos são ideias que se interligam umbilicalmente ${ }^{42}$.

\footnotetext{
41 "Era natural que, ao longo de semelhante processo de amadurecimento, os maiores cuidados se dirigissem à construção de estruturas dogmáticas firmes. Tal prioridade refletia, aliás, o conceptualismo que reinava, quase absoluto, no ambiente jurídico da época. Manifestações dessa tendência são, por exemplo, as aturadas e por vezes acerbas polêmicas doutrinárias em torno da natureza da ação, da coisa julgada, do objeto do processo". MOREIRA, José Carlos Barbosa Moreira. Tendências contemporâneas no direito processual civil. In: Temas de direito processual. Terceira série. São Paulo: Saraiva, 1984, p. 2.

${ }^{42}$ Nas ações que envolvem a proteção às marcas registradas, não há que se confundir a tutela antecipada com o ressarcimento pecuniário. Não obstante o fato ambas as espécies de tutela terem sido tratadas no mesmo artigo 209 da Lei da Propriedade Industrial, enquanto o caput do artigo faz referência à tutela ressarcitória, o parágrafo único cuida exclusivamente da tutela preventiva.
} 
A tutela inibitória é a tutela mais comum utilizada para fins de proteção de direitos marcários. Entendese, nesse sentir, que a citada tutela seria o instrumento mais eficaz para o resguardo desses direitos, seja em virtude da atração que sinais distintivos exercem sobre os consumidores, seja em razão da necessidade de manutenção do investimento das marcas notórias e até mesmo para resguardar a confidencialidade de informações classificadas como relevantes para a competitividade empresarial ${ }^{43}$.

Sem embargo, como ressaltam alguns doutrinadores, a tutela inibitória sem possibilidade de antecipação de tutela carece de utilidade. Melhor explicando, "retirar da inibitória sua fase liminar sumária é castrá-la naquilo que lhe outorga maior efetividade. A inibitória sem a possibilidade de liminar é uma cominatória relativamente aprimorada" ${ }^{44}$.

Ao olhar para o direito comparado, Luiz Fernando Pereira ${ }^{45}$ chama atenção para o fato de que no direito inglês, é quase impossível se conceber uma ação judicial que envolva conflitos marcários que não seja antecedida de uma "preliminary injunction". E assim prossegue o autor em sua pesquisa:

"O artigo 99 do Regulamento 40/94 da Comunidade Europeia, também vale citar, obriga os Estados membros a aplicarem medidas liminares na defesa dos direitos de marca e patente. Em Direito Industrial, a importância da liminar antecipatória é tanta que a legislação de marcas e patentes italiana se preocupou em conceber apenas a inibitória sumária. Até hoje a doutrina e jurisprudência italiana debatem, sem muito sucesso, a natureza da inibitória final. É o reconhecimento de que a tutela efetiva da propriedade industrial está intimamente relacionada à fase antecipada da inibitória".

É inolvidável, assim, a importância da tutela antecipada para fins de garantia da efetividade do direito marcário, retirando do titular de uma marca o ônus de suportar as mazelas decorrentes do transcurso do tempo. A estabilização da tutela antecipada potencializa essa efetividade, evitando processos longos e morosos quando assim as partes não desejarem.

Em verdade, o processo serve às partes. Logo, se estas não desejam litigar e se contentam com a concessão do pleito antecipatório em sede de ação inibitória ${ }^{46}$, encontra-se finalizado o papel do processo.

A estabilização da tutela antecipada, por conseguinte, reflete uma conquista insofismável do direito processual. Mas, não é necessário muito esforço para que se conclua que é no direito marcário que a ideia de estabilização ganha seu contorno mais forte. Isso ocorre porque, diferentemente do que costumeiramente ocorre, a tutela antecipada em ação inibitória é eminentemente satisfativa. Por isso, "a inibitória antecipada antecipa a

\footnotetext{
${ }^{43}$ DIAS, José Carlos Vaz [et al]. The Legal Treatment of Know-How in Brazil: Peculiarities and Controversies of a New Intangible Form. Quaestio Juris. Vol. 09, no. 04. Rio de Janeiro: 2016, p. 2312 -2334. Disponível: http://www.epublicacoes.uerj.br/ojs/index.php/quaestioiuris/article/view/26295. Acesso em 15 de dezembro de 2016. ${ }^{44}$ PEREIRA, Luiz Fernando. Op. cit., p.178. 45 Idem, p. 179.

${ }^{46}$ Como bem adverte Luiz Fernando Pereira, "a inibitória antecipada julga o mérito, ainda que em cognição sumária (...). A tutela antecipada em ação inibitória é um provimento eminentemente satisfativo, porque antecipa exatamente o mesmo provimento inibitório final". Idem, p. 181.
} 
mesma inibitória que deverá advir da sentença definitiva" ${ }^{\text {"7 }}$.

\section{APLICABILIDADE DAS TUTELAS DE URGÊNCIA E DE EVIDÊNCIA PARA FINS DE PROTEÇÃO DAS MARCAS: O SURGIMENTO DA TUTELA DA EVIDÊNCIA COMO CONSAGRAÇÃO DA PROTEÇÃO EFETIVA}

Consoante mencionado no capítulo anterior, não há como se negar a importância da tutela de urgência para fins de proteção marcária, principalmente das ditas tutelas antecipadas.

Contudo, os titulares de determinados bens jurídicos (em especial aqueles em que o periculum in mora não se comprova com a mesma facilidade do que direitos que envolvem diretamente a vida e a liberdade) sempre encontraram um considerável obstáculo à concessão da tutela antecipada. É o que acontece, sem dúvidas, com os direitos marcários, os quais são tidos, historicamente, como direitos proprietários e eminentemente patrimoniais.

No âmbito dos bens intangíveis ${ }^{48}$, as tutelas antecipadas vieram sempre atreladas à evidência do "dano irreparável ou de difícil reparação", prevista no artigo 209, $\$ 1^{\circ}$ da Lei da Propriedade Industrial, requisito que restringia sobremaneira a possibilidade de inibir a continuidade do dano dos bens jurídicos protegidos pelo direito da propriedade industrial.

O problema todo reside no fato de que, como se sabe, a concessão da tutela de urgência depende do preenchimento de dois requisitos (unificados para todas as modalidades de tutela de urgência com o NCPC): periculum in mora e fumus boni iuris.

A caracterização do perigo da demora no direito das marcas, como dito alhures, encontra grande resistência por parte do poder judiciário (que, por muitas das vezes, na dúvida, opta pela não concessão da referida tutela).

O legislador do NCPC, todavia, sensível ao fato de que o periculum in mora (diferentemente do fumus boni iuris, que pode ser aferido de maneira mais objetiva), em muitas hipóteses, é analisado de maneira subjetiva, criou a tutela da evidência, uma espécie de tutela provisória que não depende de urgência.

O diploma processual de 2015, ao criar a tutela da evidência, passa a não mais exigir o requisito urgência, bastando, para que se assegure ao titular de um direito o seu efetivo gozo, a existência de uma probabilidade acentuada de existência do direito. Ou seja, presente um fumus boni iuris qualificado, por que não conceder ao titular de um direito a sua efetiva fruição?

\footnotetext{
${ }^{47}$ FERRARA JR., Francesco. Brevi riflessioni sulla sentenza di inibitória nel corso del giudizio di violazione dei diritti de brevetto per invenzioni industriali o per marchi di impresa. Rivista di Diritto Industriale, I, 1961, p. 13.

${ }^{48}$ Os intangíveis protegidos pelo direito da propriedade industrial são as marcas e os sinais distintivos, as patentes de invenção, os modelos de utilidade, os desenhos industrias, as cultivares e os circuitos integrados, conforme disposto nas Leis no ${ }^{\mathrm{S}}$. 9.279, de 15 de maio de 1996; 9.456, de 25 de abril de 1997 e 11.484, de 31 de maio de 2007.
} 
Alexandre Câmara ${ }^{49}$, ao conceituar o instituto, assevera que estamos diante de uma tutela antecipada não urgente:

"Denomina-se tutela da evidência a tutela provisória, de natureza satisfativa, cuja concessão prescinde do requisito urgência. Trata-se, então, de uma tutela antecipada não urgente, isto é, uma medida destinada a antecipar o próprio resultado do prático final do processo, satisfazendo-se na prática o direito do demandante, independentemente da presença de periculum in mora. Está-se, aí, pois, diante de uma técnica de aceleração do resultado do processo, criada para casos em que se afigura evidente a existência do direito material".

Para os detentores de marcas violadas, não há dúvidas de que o instrumento em questão possui aplicabilidade incontestável, o que se afere por meio de uma leitura perfunctória do artigo $311^{50}$, inciso II do NCPC.

Ao prever a possibilidade de antecipação de tutela sem a configuração da urgência na norma delineada no artigo 311, inciso II (hipóteses nas quais as alegações de fato possam ser comprovadas documentalmente), criou-se um instrumento capaz de satisfazer imediatamente o direito dos titulares de marcas violadas, porquanto a comprovação da violação de direitos marcários é usualmente comprovada em petição inicial, sendo apenas corroborada no decorrer do processo.

Com o fumus boni iuris configurado de maneira incontestável, não mais se justifica eventual decisão que indefira a antecipação com base em uma suposta ausência de urgência. Ademais, é permitida a concessão liminar da tutela antecipada na hipótese do citado inciso II, com o intuito de por fim em decisões genéricas que negam os pedidos de tutela por ausência de perigo de dano irreparável ${ }^{51}$.

A tutela da evidência cria, por consequência, isonomia no que diz respeito à distribuição do ônus do tempo no processo, o que é extremamente importante em um processo que pretende ser célere, justo e igualitário.

Por fim, há que se ressaltar que a criação da tutela de evidência vem ao encontro do entendimento

${ }^{49}$ CÂMARA, Alexandre Freitas. Op. cit., p. 171.

50 Art. 311 . A tutela da evidência será concedida, independentemente da demonstração de perigo de dano ou de risco ao resultado útil do processo, quando:

I - ficar caracterizado o abuso do direito de defesa ou o manifesto propósito protelatório da parte;

II - as alegações de fato puderem ser comprovadas apenas documentalmente e houver tese firmada em julgamento de casos repetitivos ou em súmula vinculante;

III - se tratar de pedido reipersecutório fundado em prova documental adequada do contrato de depósito, caso em que será decretada a ordem de entrega do objeto custodiado, sob cominação de multa;

IV - a petição inicial for instruída com prova documental suficiente dos fatos constitutivos do direito do autor, a que o réu não oponha prova capaz de gerar dúvida razoável.

Parágrafo único. Nas hipóteses dos incisos II e III, o juiz poderá decidir liminarmente.

${ }^{51}$ “Tendo em vista que não há perigo de dano irreparável, entendo por bem apreciar a pedido de antecipação dos efeitos da tutela após a resposta. Cite-se". Decisão proferida nos autos do processo no . 0108671-66.2010.8.19.0001 (TJRJ; 6a Vara Empresarial; publicada em 12/04/2010). Disponível: http://www4.tjr.jus.br/consultaProcessoWebV2/consultaMov.do?v=2\&numProcesso=2010.001.0972769\&acessolP=internet\&tipoUsuario=). 
doutrinário que já prevalecia na seara do direito industrial, inclusive no direito comparado ${ }^{52}$. Entendia-se, antevendo o próprio futuro do processo, que o perigo de dano deveria ser tido como presumido sempre que o fumus boni iuris qualificado estivesse presente ${ }^{53}$.

Ante tais fatos, é de uma clareza solar que o NCPC descortina um novo direito marcário (e quiçá um novo direito da propriedade industrial), possibilitando que se ponha em realce a sua faceta não-patrimonial (tão defendida por inúmeros autores de escol).

Põe-se, finalmente, uma pá de cal no enferrujado entendimento que prevalecia entre os magistrados, no sentido de que violações marcárias sempre são resolvidas por meio da tutela ressarcitória.

\section{CONCLUSÃO}

Conforme apresentado, as alterações promovidas pelo NCPC são de inegável importância no tocante à aplicação das tutelas de urgência na seara marcária. Por óbvio, não se pode deixar de mencionar que também reconhecemos a importância genérica das mudanças promovidas ao titular de qualquer direito, seja ele de cunho pessoal, seja ele de cunho patrimonial.

Independentemente da alteração a que se faça referência (uniformização dos requisitos para a concessão das tutelas de urgência; estabilização da tutela satisfativa; ou o surgimento da tutela da evidência), é relevante que a sua aplicação no cenário marcário cria uma esperança de efetividade para os titulares desse direito da propriedade industrial.

Infelizmente, somente será possível constatar se as inovações tão festejadas do NCPC surtirão o efeito prático positivo esperado com o passar do tempo. Somente o tempo será capaz de permitir o amadurecimento doutrinário e jurisprudencial sobre os institutos novos ou reformulados pelo legislador.

De nada adiantam as mudanças positivas contempladas se não for assegurada a observância real do NCPC, sob pena de as inovações implementadas não passarem de meras promessas.

O que se espera é que o NCPC tenha a aptidão de rejuvenescer o aplicador do direito brasileiro, abrindo os olhos dos julgadores para temas atuais que sempre foram relegados ao limbo, como é o caso dos direitos da propriedade industrial.

A realidade moderna não mais admite o tratamento desfavorecido conferido ao titular de um direito patrimonial, historicamente tido como um direito secundário.

\footnotetext{
52 "O correto é que, para boa parte da doutrina italiana especializada, o requisito do periculum se revela ínsito no fenômeno da contrafação. Nos Estados Unidos se presume o prejuízo irreparável em propriedade intelectual, como requisito da preliminary injunction. Em concorrência desleal chega-se a afirmar que a tutela sumária tem como pressuposto unicamente o fumus boni iuris. O periculum seria sempre presumido". PEREIRA, Luiz Fernando. Op. cit., p.184.
} 
O simples fato de um litígio envolver um direito eminentemente patrimonial não retira a importância de um pleito antecipatório, o qual, em muitos dos casos, pode ser fundamental para a sobrevivência daquele direito. Relegar toda e qualquer solução para a tutela ressarcitória viola frontalmente a justiça que se espera das decisões prolatadas pelos órgãos judiciais.

Como exaustivamente mencionado, não há como se admitir uma tutela inibitória que se proponha a proteger direitos de propriedade sobre marcas sem a prévia concessão de uma tutela antecipada. A tutela inibitória somente conseguirá exercer o seu potencial preventivo se acompanhada de uma tutela antecipada.

Por muitos anos, essa constatação não foi visualizada de forma tão clara pelos operadores do direito. Mas, espera-se (e confia-se) que, com o NCPC, essa realidade absurda venha a ser modificada, de forma a não mais se privilegiar o contrafator que, muitas das vezes, recebe um "aval" do Judiciário para dar continuidade nos atos ilícitos perpetrados, sob o argumento de que tudo se resolverá em perdas e danos.

O direito nunca teve tanta pretensão de se aproximar da justiça como ocorre nos dias de hoje. Isso faz com que os reflexos sejam irradiados para todo sistema jurídico. E o NCPC reflete essa mudança de postura, em uma tentativa velada de mudar o próprio julgador, haja vista que "os juízes, hoje, começam a ensaiar a possibilidade de serem porta-vozes não só da segurança dos que já têm, mas também da esperança dos muitos que ainda não têm ${ }^{\prime \prime 4}$.

Neil Andrews já abria os nossos olhos para a necessidade de criação de uma jurisdição capaz de obter resultados justos e eficazes ${ }^{55}$. O NCPC está nos permitindo mudar - e isso se evidencia de maneira contundente, como vimos, no direito marcário e no direito da propriedade industrial. Não percamos a chance que estamos tendo de transformar o direito em um instrumento da justiça e efetividade, principalmente para os bens juridicos intangiveis.

\footnotetext{
${ }^{53}$ Autores como Guilherme Pupe de Nóbrega entendiam que o Código do Consumidor já dispunha da possibilidade de obter tutela definitiva, de maneira antecipada, em caráter restritivo, nos termos do $\$ 4^{\circ}$. do art. 84 do CDC. NOBREGA. Op. cit. Pág. 66. 54 FACCHINI NETO, Eugênio. O Judiciário no mundo contemporâneo. Revista da Ajuris, ano XXXIV, no. 108, 2007, p. 139145 .

${ }^{55}$ ANDREWS, Neil. The three paths of justice. Court proceedings, arbitration, and mediation in England. London: Springer, 2012, p. 48.
} 


\title{
THE SYSTEMATICS OF PROVISIONAL TUTORIALS IN THE NEW CIVIL PROCESS CODE AND ITS INFLUENCE ON BRAZILIAN TRADEMARK LAW
}

\begin{abstract}
This work deals with the main alterations promoted by the new Brazilian Civil Procedural Code (NCPC) in relation to provisional measures, highlighting the importance of the proposed modifications to the industrial property rights, mainly the trademark law. The objective of this work is to examine how the ideal efficacy obtained by the new ruling can affect the protection of rights historically neglected, as it is the case of trademarks.
\end{abstract}

Keywords: New Civil Procedural Code, provisional protection, trademark law, industrial property law, effectiveness.

\section{REFERÊNCIAS BIBLIOGRÁFICAS}

ANDREWS, Neil. The three paths of justice. Court proceedings, arbitration, and mediation in England. London: Springer, 2012, p. 26.

BARBOSA, Denis Borges. Bases Constitucionais da Propriedade Intelectual. Revista da ABPI, no 59. Rio de Janeiro: jul/ago 2002.

CABRAL, Antônio do Passo. A duração razoável do processo e a gestão do tempo no projeto de novo código de processo civil. In: FREIRE, Alexandre [et al] (Coord.). Novas tendências do processo civil. Salvador: Jus Podivm, 2013.

CÂMARA, Alexandre Freitas. O Novo Processo Civil Brasileiro, 2a edição. Rio de Janeiro: Atlas, 2016.

DIAS, José Carlos Vaz. Business Transaction of Intellectual Intangibles: The Evidence and Peculiarities of a New Form of Property Rights. Questio Iuris. Rio de Janeiro: v. 8, n. 3, 2015, p. 2044-2066.

New Dress Code for Business Transactions in Brazil: Essentials and Peculiarities of Trademarks in the Spotlight. In: CALBOLI, Irene; WERRA, Jacques (ed.) The Law and Practice of Trademark Transactions: a Global and Local Outlook. Edward Elgar Publishing, 2015.

DINAMARCO, Cândido Rangel. Escopos políticos do processo. In: Participação e processo. São Paulo: Revista dos Tribunais, 1988.

FACCHINI NETO, Eugênio. O Judiciário no mundo contemporâneo. Revista da Ajuris, ano XXXIV, nº. 108, 2007.

FERRARA JR, Francesco. Brevi riflessioni sulla sentenza di inibitória nel corso del giudizio di violazione dei diritti de brevetto per invenzioni industriali o per marchi di impresa. Rivista di Diritto Industriale, I, 1961.

HARTMANN, Rodolfo Kronemberg. Novo Código de Processo Civil. 2a Ed. Rio de Janeiro: Impetus, 2016.

JOBIM, Marco Félix. Cultura, escolas e fases metodológicas do processo. Porto Alegre: Livraria do Advogado, 
2011.

KOATZ, Rafael Lorenzo. A proibição do non liquet e o princípio da inafastabilidade do controle jurisdicional. Revista de Direito Administrativo. Rio de Janeiro: v. 270. Disponível: http://bibliotecadigital.fgv.br/ojs/index.php/rda/article/view/58741/57534.

MARINONI, Luiz Guilherme. Teoria geral do processo. 2. Ed. São Paulo: Revista dos Tribunais, 2007.

MARTINS, Rui Cunha. O ponto cego do direito. The brazilian lessons. 2. Ed. Rio de Janeiro: Lumen Juris, 2011.

MOREIRA, José Carlos Barbosa. O futuro da justiça: alguns mitos. In: Temas de Direito Processual. Oitava Série. Rio de Janeiro: Editora Saraiva, 2004.

Tendências contemporâneas no direito processual civil. In: Temas de direito processual. Terceira série. São Paulo: Saraiva, 1984.

NEVES, Castanheira. Entre o legislador, a sociedade e o juiz ou entre sistema, função e problema - os modelos actualmente alternativos da realização jurisdicional do direito. Boletim da Faculdade de Direito, v. LXXIV. Coimbra: Universidade de Coimbra, 1998.

NEVES, Daniel Amorim Assumpção. Manual de Direito Processual Civil. 3ª Ed. São Paulo: Gen / Método, 2011.

NEVES, Marcelo. Constituição simbólica. Pernambuco: Martins Fontes, 1998.

NOBREGA, Guilherme Pupe da. O CPC/2015 e a Tutela Provisória de Urgência Antecipada. In: Processo Civil em Debate. Organizado por Janete Ricken Lopes de Barros e Guilherme Pupe da Nóbrega. IDP. Brasília: 2015, p 59. Disponível em: http://www.idp.org.br/component/docman/doc_download/906-direito-processual-civil.

PEREIRA, Caio Mário da Silva. Instituições de Direito Civil. 8a ed. Rio de Janeiro: Forense, 2004.

PEREIRA, Luiz Fernando. Tutela jurisdicional da propriedade industrial. Aspectos processuais da Lei 9.279/1996. São Paulo: RT, 2006.

REQUIÃO, Rubens. Curso de Direito Comercial. Vol. 1. São Paulo: Saraiva, 2015.

TEPEDINO, Gustavo. A Nova Propriedade (O seu Conteúdo Mínimo, entre o Código Civil, a Legislação Ordinária e a Constituição). Revista Forense, 306.

WATANABE, Kazuo. Acesso à justiça e sociedade moderna. In: Participação e processo. São Paulo: Revista dos Tribunais, 1988.

Trabalho enviado em 09 de julho de 2017.

Aceito em 17 de julho de 2017. 